\title{
Reflecting on more than 20 years of involvement in a postgraduate higher education qualification for academics: May I dare use an auto-ethnographic lens?
}

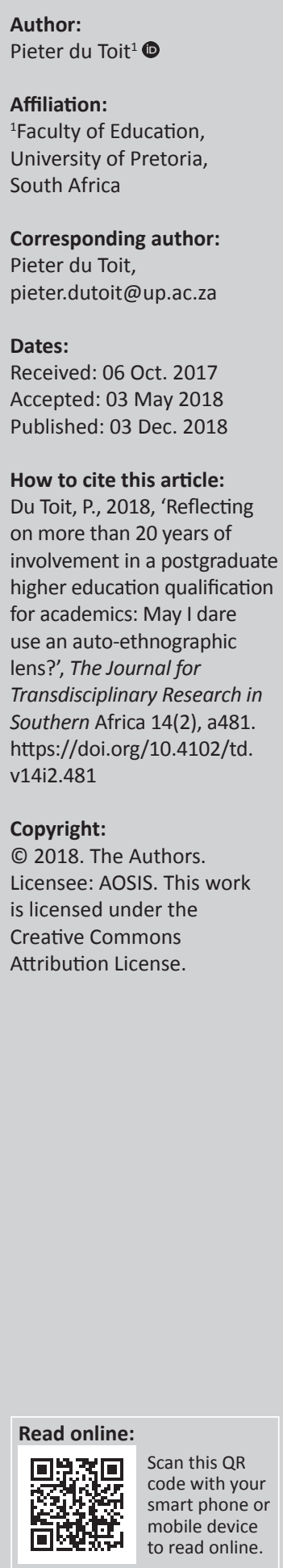

As a proponent of action research for more than 20 years, I reflect on my scholarship of higher education using an auto-ethnographic lens. The research reported focuses mainly on my facilitating of learning as a lecturer at the University of Pretoria, one of the largest residential universities in South Africa. Through informal educational professional development I am involved in offering workshops to academic staff and become involved in complementing research projects. I am the coordinator of the Postgraduate Certificate in Higher Education (PGCHE), a mainstream educational professional development programme offered at the Faculty of Education. The objectives of the study are to make public my reflecting on my reflection, which forms part of my action research. I do this with a view to encouraging practitioners of action research to do the same. An action research spiral is executed, complemented by cycles of reflection. Quantitative and qualitative data are collected. In this article the focus is on qualitative data. It comes in the form of narratives and visuals. The visuals include brain profiling. Narratives are derived from student feedback. The underpinning epistemology is constructivism. By means of the action research teaching practice is enriched. A higher order of reflection is promoted - identified as scholarly meta-reflection. All scholars of higher education and action research should take a meta-level approach to reflecting on practice: within an action research paradigm - reflecting on reflection at a high level of scholarship.

\section{Intermezzo}

My reflection on the educational professional development of academic staff includes some of my colleagues and myself. I focus on the educational professional development initiatives I have been involved in over more than 20 years. As the context is higher education, the professional development revolves around the responsibilities of academic staff in terms of their higher education practice - their responsibilities and professional roles (Department of Education $2000 \mathrm{~b}$ ) to be enacted and mine. My higher education practice at one of the largest researchintensive universities in South Africa offering students the opportunity to enrol in programmes in nine faculties is the main focus. I use an auto-ethnographic lens. My practice is both formal and informal in nature. The formal entails a higher education postgraduate programme offered as a mainstream programme by the Department of Humanities Education in the Faculty of Education. This qualification developed through a number of curriculum development iterations. First it was called a Diploma in Tertiary Instruction. Next a Postgraduate Diploma in Higher Education. This was followed by yet another renaming, alias the United Kingdom (UK) model, currently known as the Postgraduate Certificate in Higher Education (PGCHE). And recently under a process of continuous curriculum development it reverted back to a Postgraduate Diploma in Higher Education. This qualification will most probably be offered as from 2018 to 2019. The PGCHE is often complemented by informal professional development initiatives. It includes short courses that are offered through the entity responsible for continuing education at the university, recently renamed. Initially it was called Continuing Education at the University of Pretoria (UP) (ce@up); currently it is known as UP Enterprises. Modules of the PGCHE are selected according to specific client needs. These modules are credit bearing. On successful completion of these modules a candidate may enrol for the remainder of the mainstream programme. In this way numerous lecturers from other universities or colleges for technical and vocational education and training have completed the PGCHE. 
After teaching at high school level for a short period of time, I decided to specialise in higher education. This led me to completing a master's and $\mathrm{PhD}$ in higher education, both at the University of Pretoria. I joined the university, as I was offered a position as education consultant, taking responsibility for the educational professional development of academic staff in two faculties. Following this, I joined a university of technology, at the time called a technikon, as deputy director responsible for academic staff development and research. I then was offered a position as lecturer at the Faculty of Education at my alma mater.

In this article I journey through my professional career as a higher education practitioner and stop at some key points. I use my auto-ethnographic lens that is reflexive in nature to do so. This lens I am referring to can only be used by the self - me in this case, as is reflected in the word particle auto of the construct auto-ethnographic. The word particle ethno refers to a community - in my case a distinct community, namely a scholarly community of higher education practice. In other words, I am a scholar of higher education among other scholars of higher education. I can only be considered a scholar when other scholars, especially those from the same field of study, would value my work as scholarly. Looking through this lens allows for reflecting on my professional past. Questions such as the following come to mind: How would I introduce myself as an academic to another academic? How did I get into higher education? Why would I consider myself as a leader in my field? These questions are implied in the ontological research question I refer to below and the entire narrative. In answering these questions my lens is also both reflexive and critical as Adams and Manning (2015) explain what an autoethnographer does.

I follow a style of reporting true to my scholarly DNA, which is less traditional. However, I do want researchers taking a more traditional approach to their research to engage with my work by referring to constructs they are familiar with such as research problem, research question, research design and conceptual framework - tinted in different shades. My breaking away from traditional ways of conducting and reporting research is based on a number of reasons. First and foremost, more often than not it is 'tradition' to report research using the third person style of writing. In doing so the researcher 'becomes detached from the research' conducted. This is my view, which resonates with the view of other advocates of action research - scholars of international standing. Since I was a first-year student one of the key points in my academic journey - it has been beyond my comprehension why I was forced to do the same. Why write about something you had done but 'distance' yourself from it? Of course, I realise that such a statement will be considered to be a generalisation - perhaps condemned. But none of my lecturers or professors or any scholar over many years could ever give me a justified explanation, except for: This is how it is done. This was the case until I met scholars of note such as Jean McNiff and Ortrun Zuber-Skerritt - another key point - whom I consider as my first mentors in true scholarship, advocating the emancipatory stance scholars should take by writing in first person. Since that point in time I have had no mentor. In saying this - also a generalisation perhaps - I do not at all negate the fact that many professors, lecturers, colleagues and my students contributed to my professional development in different ways. Yet 'back home' as I have started embarking on my journey of becoming a scholar in my own right, I have been bombarded by the one (traditional) way of doing research. I had to come up with numbers and graphs and the refrain in my mind echoed: 'quantitative data', 'empirical research', 'empirical data', 'empirical study', as if the real world and looking at and into it is only a quantitative cosmos. Any other means of reporting that I found of value through my research, for example narratives, objects, photo evidence, reflective journals, were frowned upon and still are by some of my colleagues. And not using 'traditional' terms and not structuring research reports in the same way as others do, by using headings such as 'problem statement', 'rationale', 'purpose', 'aim', 'objectives', made me an 'other'. Breaking away from a single, preferred, proposed, expected way of conducting research - a limitation in terms of unleashing my potential - was emancipatory. And it was this emancipatory experience that I wished and still wish for my students. I experience my students - lecturers specialising in an array of fields of study, such as medicine, veterinary science, accounting, engineering, who are familiar with and used to doing traditional research - to be quite hesitant when I expect them to do a self-enquiry study or action research of teaching practice. They would frown upon my expectation that they write in the first person, that they realise that research that includes pre- and post-tests as is to be found in comparative studies is not a necessity when one researches one's own teaching practice. Expecting an engineer, an accountant or a veterinary practitioner to write a poem about how they would like to conduct research, or to enrich a theoretical framework, is quite daunting. However, challenging them to do so, to think out of their comfort zone of explaining their research design, and rather have them write a poem on action research, they become creative, non-traditional researchers. Evidence of writing such poems as a scholarly act is to be found in poems published in De Boer et al. (2013) and readers for students (Du Toit 2017).

Another reason for opting out of the traditional way of conducting research, which I consider a principal reason, is that I have to act as a transformational leader in higher education. In this endeavour, acting as a transformational scholar becomes evident. My scholarly discourse and narratives are in the first place tinted by writing in first person format as alluded to above. And, according to my thinking preferences as determined by means of the Herrmann Brain Dominance Instrument (HBDI ${ }^{\circledR}$ ) (Herrmann 1995, 1996; Herrmann \& Herrmann-Nehdi 2015) as another 
tint - making my lens multifocal - an auto-ethnographic lens and action research are a perfect fit. Furthermore, what I cannot negate is the fact that over the past 20 years of reflecting political and historical tints are to be added to my lens. A new dispensation in the form of a new government changed the entire South African landscape - South African life - in all its dimensions, specifically in higher education, the latter being informed by the founding of a new Department of Higher Education and Training that previously did not exist. Closer to home, working under the leadership of the very first black dean appointed in the Faculty of Education contributed to opening my eyes to an authentic South African society. An authentic world of work where I more and more have to rethink what I do from an African tint perspective. Making way for diverse thinking in terms of higher education and including indigenous knowledge was initially a challenge until I realised that, honouring my education philosophy of socio-constructivism, all students, representing different cultures, were allowed to contribute to constructing the curriculum by means of constructing own meaning. They were to create their own practice theory because the application of different educational principles differs from one context to the next. Referring to 'students representing different cultures' marks another key point in my academic journey. Having mostly white students sitting in my class, working with the professional development of mostly white academics changed to working with students and academics from all cultures, especially Africans.

When reflecting on my contribution to higher education in general and specifically at my university - viewing myself as a leader - it is not at all meant to be a case of academic arrogance. I do so simply because one of the roles of a lecturer (Department of Education 2000b) and an attribute of the 21st century (Du Toit 2017) expects all citizens to contribute to building the nation as leaders. I consider my leadership as multilayered and transformational. From a hierarchical, organogram point of view I progressed from a lecturer teaching on the programme, to senior lecturer assigned the responsibility of taking a leadership position as programme coordinator of the PGCHE. At structural level, I enacted my leadership role in curriculum development. I enacted this role in revising the curriculum to a qualification well known by academics at the university. Academics who enrolled in the programme and others who would attend short courses linked to the programme. At a practice level I endeavour to take a leadership position as a role model to my students - transforming my practice, with the intention of observing them transforming theirs. Realising that my students implement what they have learnt on the programme in their practices gives me a sense of satisfaction regarding the contribution I have made and am still making to creating opportunities for professional development that will be emancipatory - allowing them to transform themselves. Proof of their transformation is evident in articles they publish and their presentations at conferences. And personal feedback or emails of claims they make of acting as transformational leaders in class owing to attending the PGCHE: some are mentioned below. My leadership is educational in my world of work. My students' leadership is educational and an attribute of the 21 st century as it is to be enacted in their specific context their world of work. Our respective worlds of work differ in the sense that I am from the Department of Humanities Education in the Faculty of Education, specifically from the Division of Higher Education and Professional Development; they are from other faculties, which focus on other fields of specialisation. At a scholarly level, my leadership takes, inter alia, the form of editorship. At national level I have acted as guest editor of a journal focusing on higher education: the South African Journal of Higher Education. At international level I have acted as editor of the ALARPM journal, published in Australia: the Action Learning Action Research and Process Management Journal. Another example of my leadership responsibility enacted is by conducting workshops on action research. This is done at a local and international level. For example, I have conducted such workshops at the University of Nottingham in the UK and the University of Tübingen in Germany. This is apart from the numerous conference papers that are proof of leader-scholarship. In the past my colleagues and I were at times confronted by the leadership of our faculty, being asked: What is your international standing? This is quite an intrapersonal question that only I can answer.

\section{Innovative research idea}

I use the construct innovative research idea instead of the traditional problem statement. I do so as I follow an assetbased approach (Du Toit 2016a) to self-enquiry. I consider the self as the most important asset in any educational setting - human capital that forms the epicentre of professionalism, with thinking preferences as attributes of any professional as asset. As alluded to in the introduction section I considered myself as such a professional and still do. The status of my professionalism, however, has transcended from just being a professional by name to being a professional in action. It was a rebirthing (Du Toit \& Van Zyl 2006). I came from a theoretical space where one was 'investigated' from a distance by others. More often than not by my superiors and external examiners and panels of scholars responsible for external auditing of my programme - to an authentic space of self-enquiry. The 'others' now have become the 'self'.

Instead of asking research questions that would force me to do as the others did, I ask ontological and epistemological questions from an intrapersonal point of view. The construct intrapersonal as part of both my ontological and epistemological stance is derived from the work of Herrmann (1995, 1996), Gardner (1993), De Boer et al. (2013), De Boer, Du Toit and Bothma (2015) and Slabbert, De Kock and Hattingh (2009). Being self-smart is the construct Gardner (1993) uses, which he aligns with intrapersonal intelligence. This means of being 
intelligent is integral to auto-ethnography, action research, self-enquiry and reflexive practice.

Intrapersonal suggests reflecting from within and asking about self-knowing and how one comes to know and thinking about one's knowing and getting to know. Keeping this notion in mind I constantly have to ask myself: Who am I as a scholarly higher education practitioner? This question intertwines the ontological and epistemological dimensions of my scholarly DNA. In essence, self-enquiry, where self represents the ontological and enquiry represents the thinking about the self - the epistemological dimension.

\section{Construct process}

Being an advocate of action research and self-enquiry, constructivist thinking tints my way of conducting research. As a constructivist, I for some time battled with the shading of constructs commonly used, such as theoretical framework or conceptual framework. I recently came across a tinted version, namely conceptual argument, and another, conceptual canvas. I valued it as innovative and used it once. But soon I realised that it does not reflect the essence of the process of constructing new meaning. I tinted my meaning making as construct process. In doing so, the continuous process of meaning making is progressed, as the term framework per se is much too restricting. Research - my research - as an authentic endeavour is frameless. It is the reporting that is restricting - as prescribed by universities, conference organisers or journals. As a constructivist and practitionerresearcher I allow myself the freedom of making new meaning. Making new meaning is continuous and therefore the theoretical subsection is merged with the gathering and analysis of data.

Constructing meaning is a scholarly responsibility I have. I have to enact related competencies with a view to act as role model for my colleagues who are enrolled for the mainstream programme - my students. Or colleagues who attend professional development opportunities I initiate, namely short courses or workshops. These initiatives complement the notion of an asset-based approach. This is in contrast to the use of the construct 'intervention' that is commonly used but that suggests a deficit-based approach. I acknowledge the fact that my meaning making in some cases involves my students or colleagues within a socioconstructivist context of professional development. This is evident in the numerous journal articles published or conference papers presented as co-authors. These research outputs are interdisciplinary in nature. They are a combination of my field of specialisation, namely higher education, and other fields of specialisation. Examples include health sciences (Van der Wath \& Du Toit 2015; Wium et al. 2017; Wolvaardt, Cameron \& Du Toit 2013; Wolvaardt, Lindeque \& Du Toit 2016); arts and design (Giloi \& Du Toit 2013); management (Wolvaardt \& Du Toit 2012) and others. I wrote a reflective article on a head of department at the university who was enrolled on the PGCHE (Du Toit 2016a). A number of articles were published in collaboration with colleagues at the university and other universities who attended my workshops. One such example is Lucas, Dippenaar and Du Toit (2013). I experienced and still experience the value of scholarly communities of practice. The co-authorship of the articles listed attest to this. It should be noted that, because action research is more often than not collaborative in nature, co-authorship is inevitable. Although my preference is for working as a member of a scholarly community of practice - as it relates to my thinking preferences as outlined in Table 1 - single authorship has more and more become a prerequisite of evidence of scholarship by my university. I therefore often find myself constructing meaning on my own. This is where self-enquiry and auto-ethnography become integral to constructivism as the underpinning epistemology that complements my action research. The construct self-constructivism may be appropriate.

Self-regulated learning (Knowles 1990), I argue, is a construct that I have to make authentic to my scholarship. In the context of higher education and the professional development of academic staff I prefer the constructs professional selfregulated learning and professional constructivist learning. This I do with a view to distinguish it from student learning. Combining professional constructivism and professional selfregulated learning brings about a deeper understanding and appreciation of my scholarship and how relating processes of continual professional learning, as is evident in action research, are to play out. My action research over many years and my scholarly reflection (Fringe 2013) in general over more than 20 years brought about the depth in terms of my reflection.

\section{Constructivist curriculum development}

I came to realise that my scholarly reflection supports the claims I make (Mcniff \& Whitehead 2006) of innovating and transforming my higher education practice. This practice is multidimensional. As both coordinator of the PGCHE and lecturer teaching on the programme I was and still am responsible for curriculum development, facilitating authentic learning (Slabbert et al. 2009) and ensuring that I demonstrate other education values, such as authentic assessment. An example of my belief in constructivism was operationalised when the curriculum development of the module on Research Supervision, which is an elective of the PGCHE, commenced. A socio-constructivist approach was followed. As the students who were enrolled at the time were my colleagues at the same university where I am employed, my challenge to them was to design the module themselves. They had to implement the prescribed curriculum development model of the university (Malan \& Du Toit 1991) used for many years. They had to formulate the learning outcomes they would have wanted to achieve. They had to decide on the different study units and the assessment opportunities that would have promoted authentic professional learning. As a scholarly community of practice they had to study relevant literature. They collaborated as scholars within professional cooperative learning groups. 
A study manual - a document that communicates the curriculum to students in the format prescribed by the university - was developed. As the lecturer responsible for the module I monitored the process. However, my intention was that professional self-regulated learning be operationalised. My role was to play a facilitative role in terms of their constructing of meaning. I acted as co-member of the scholarly community of practice and co-constructed a new meaning of research supervision.

What they had to include was a list of contextualised socalled critical cross-field outcomes (Department of Education 2000a). The list includes the following:

- Critically reflect on your supervision practice and complementary professional development and use a variety of strategies to learn more effectively how to improve your practice.

- Identify and solve problems you encounter in your supervision practice in an accountable way, using critical and creative thinking.

- Work with other colleagues or peers as a member of a supervision team (co-supervision) to develop your supervision skills.

- Collect, analyse, organise and critically evaluate information regarding your own supervision practice.

- Communicate effectively as supervisor using visual and verbal language skills.

These competencies fit the authentic assessment opportunities that are used to determine to what extent the colleagues (my students) are able to make claims of developing as supervisors. And claims of developing scholarship of supervision. For this purpose they have to execute action research on their supervision practice. The outcome of the action research and self-reflection should be reported in the form of a draft conference paper or a draft journal article.

The module on research supervision consists of the following study units: managing research supervision, facilitative supervision, assessing theses and dissertations and disseminating research outcomes. Assessment includes assessing a research proposal in written and oral format; informal assessment of drafts of chapters; progress reports; assessment of a final dissertation or thesis and external examination; and finally an oral examination in the case of $\mathrm{PhD}$ studies. Disseminating research outcomes includes the final dissertation or thesis, publications and conference presentations. An innovative approach to supervision was followed. For example, principles of innovative means of facilitating learning - in this case the learning of postgraduate students - were applied to the context of research supervision. Many of the principles form part of the module on Facilitating Learning. It was for the first time that the principles of thinking preferences were included in the study unit Facilitative Supervision. So far I have not come across any such a module at any other university that includes this as part of supervision. For this purpose the work of Herrmann $(1995,1996)$ is used. I would like to demonstrate this innovation by means of a case study from my supervision practice.

Applying the principles of thinking preferences in my supervision practice was transformative. My experience of the value of Herrmann's work inevitably informed my research supervision. I realise that my specific modes of thinking should be married to my students' modes of thinking. For the purpose of determining these modes of thinking, profiling is done by means of the HBDI. Such a profile is referred to as a brain profile. In some cases my profile and the profile of the student I am supervising are similar. In other cases my profile and the student's profile are opposites. I refer to the latter as the perfect mismatch. In cases like these it is important to take note of the fact that my thinking preferences and the preferences of my student complement one another. In cases where my profile and my student's profile are similar it is important to note that there are other modes of thinking - which both of us may avoid - that need to be included in a supervision practice. If organising is not one of my student's preferred modes of thinking he or she most probably would have problems with managing his or her progress in terms of executing their research. As I do not have a preference for organising, both of us need to realise that monitoring the student's progress, setting dates for submission of drafts or making appointments on a regular basis are aspects to be acutely aware of, as the university expects students to finish within a given time limit.

As an example I give an adapted version of the preferences and avoidances (Smit \& Du Toit 2016) that my profile reflects and the same for one of my master's students with a similar profile. As a supervisor with a high preference for experimenting with innovative ideas and people-orientated aspects I prefer to make supervision sessions 'fun' for my students; to create opportunities for both of us to participate in a spontaneous fashion; to make them 'playful', with surprising approaches to supervision; to work with visual representations, metaphors and overviews, discovering new meaning; to provide freedom to explore new ways of supervising postgraduate students and designing and executing research projects; to encourage a quick pace and variety in supervision format; to provide the opportunity to experiment with innovative ideas regarding supervision. What I most probably struggle with or would avoid are the following: keeping up with administration pertaining to supervising a student; detail necessary for documenting progress during the supervision; lack of flexibility. The student that I use as Respondent 1 (R1) in this case has the same preferences and avoidances as me.

In relation to my preferences in terms of being peopleorientated I prefer the following: (group) discussion and involvement during supervision sessions; sharing and expressing feelings and ideas with the student I supervise and other students; being offered opportunities for hands- 


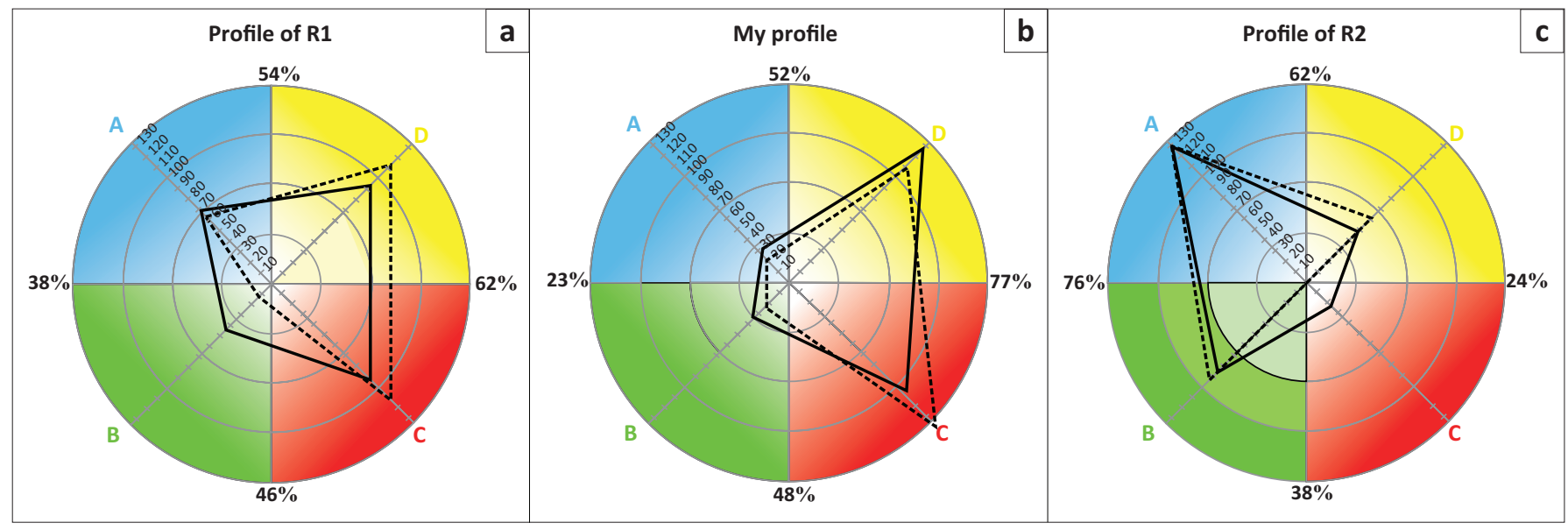

Source: Herrmann International

FIGURE 1: Visual representation of my thinking profile (b) and that of two students (a and c).

on supervision; personal connection with the student; emotional involvement; creating a user-friendly supervision experience for my student; using all my senses during supervision. What I may struggle with includes the following: too much data given by the student or too much data (information) expected in terms of administrative processes, procedures and forms; lack of personal feedback from the student.

The following example represents a case of one of my $\mathrm{PhD}$ students, Respondent 2 (R2), with a profile that is opposite to mine. She prefers precise, to-the-point information from me as supervisor and the administration office; theory and rationale for executing tasks; proof of validity; reading text a thorough literature study; working with figures, numbers and data sets; quantitative research; expertise in a field of specialisation.

What she may struggle with includes the following: expressing emotions during supervision or supervisorstudent relationships; lack of logic during supervision sessions and argumentation; communication of vague, imprecise concepts or ideas during supervision sessions.

In addition she prefers an organised, consistent approach during supervision sessions; that I honour her staying on track and on time; that I work with examples; to receive clear instructions from me; clear expectations. What she may struggle with are aspects such as taking risks; experimenting with innovative ideas; ambiguity; unclear expectations; directions from me as supervisor. This respondent and I formed a 'team' that offered both the opportunity for reciprocal learning and making the supervision process work for both of us. This brain profiling should be read in conjunction with the next subsection. In this section my preferred theory on thinking preferences is briefly outlined and a visual representation is given.

In Figure 1 my profile and the profiles of both students are represented as visuals.

\section{Brain profiling}

As the theory on thinking preferences - referred to as whole brain thinking (Herrmann 1995, 1996) - forms an essential part of my teaching practice, I did profiling of a group of PGCHE students. Their profiles are not represented as individual profiles. Instead, all the profiles are combined as a composite whole. From Figure 2 it can be deduced that the group of students have preferences in all four quadrants. With a view to inform the reader of the essence of the whole brain model, the following simple model is briefly explained.

The model in Figure 3 represents four quadrants: 'In brief the A-quadrant (blue) mainly represents fact-based learning; the B-quadrant (green) sequential learning; the C-quadrant (red) emotive thinking and the D-quadrant (yellow) experimental and holistic learning' (Smit \& Du Toit 2016).

Another way of portraying similar data is evident in Figure 4. It shows the average profile of a different group of PGCHE students.

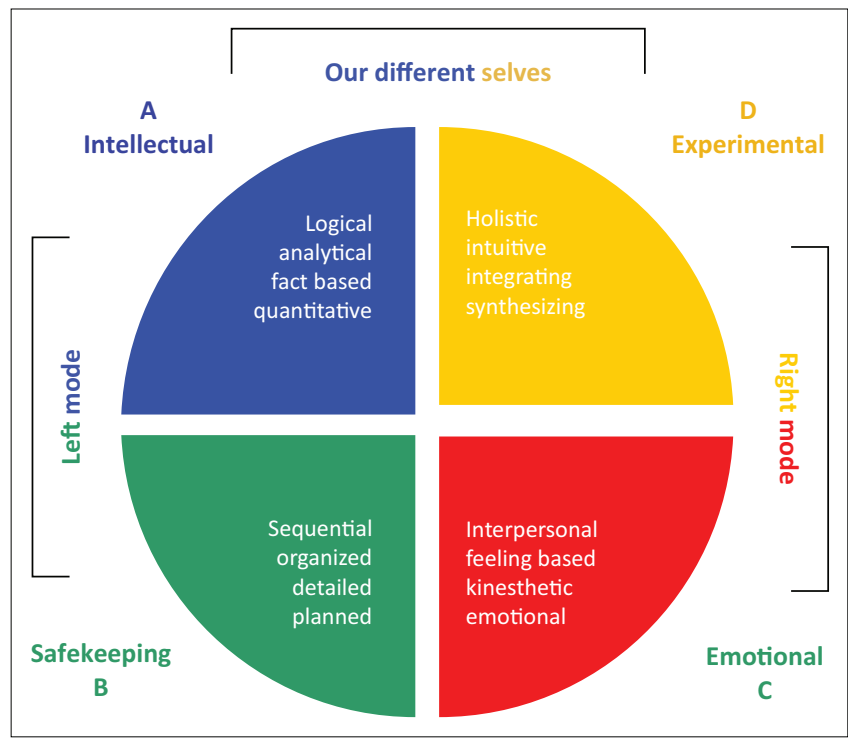

Source: Herrmann, N., 1995, The creative brain, Brain Books, Lake Lure, NC; and Herrmann N., 1996, The whole brain business book, McGraw-Hill, New York.

FIGURE 2: Metaphoric whole brain model. 


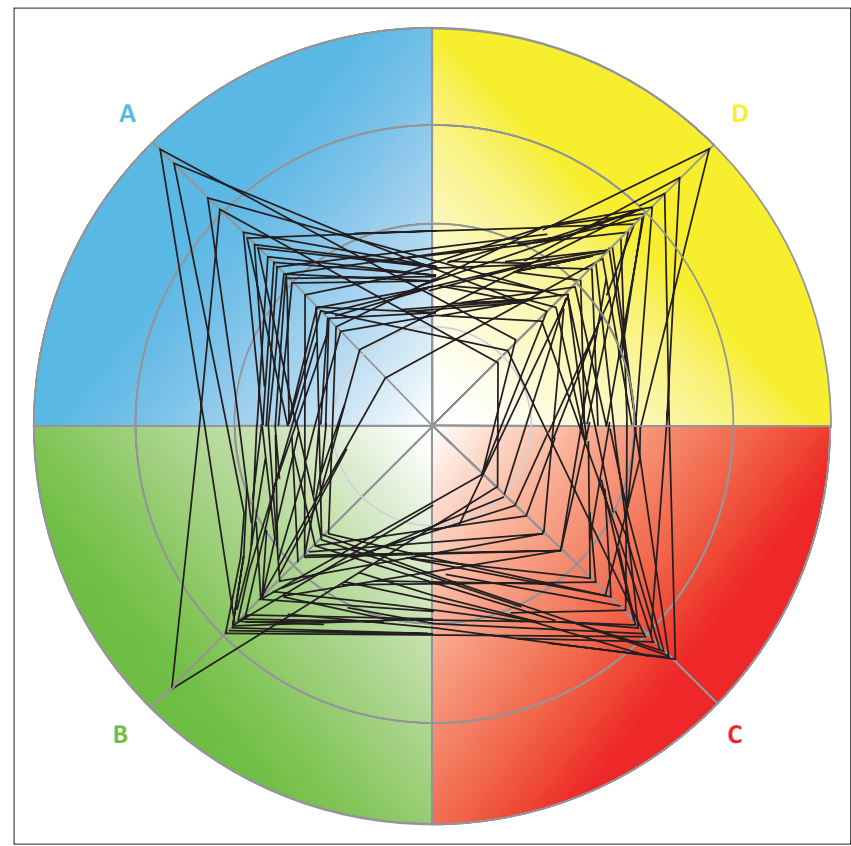

Source: Du Toit, P.H., 2017, 'Linking multiple intelligence and thinking preferences as a means to facilitating multiliteracies: Evidence-based practice', in A. Engelbrecht (ed.), Manuscript of a publication on multiliteracies, in press, Van Schaik, Pretoria.

FIGURE 3: Composite group profile of a group of Postgraduate Certificate in Higher Education (PGCHE) students.

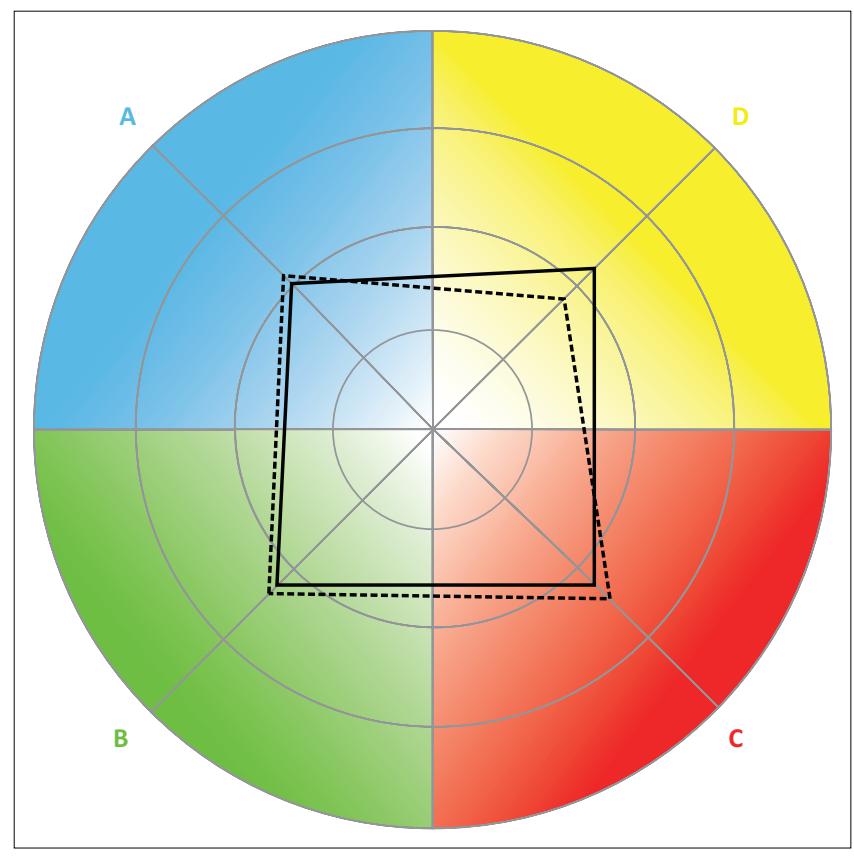

Source: Herrmann International

FIGURE 4: Average profile of a group of Postgraduate Certificate in Higher Education (PGCHE) students.

Student feedback as another means of gathering data for the purpose of using my auto-ethnographic lens is discussed next.

\section{Student feedback}

Often student evaluation is confused with student feedback and vice versa. I am of the opinion that students cannot evaluate lecturers as they are not skilled in judging whether a teaching practice is of high quality or not. One can but rely on their perceptions of their experiences. However, expecting my students to give feedback to me on my teaching practice challenges them, as professionals, to engage in scholarly reflection, scholarly discourse and higher-order thinking. It is also aligned with one of the learning outcomes stated in the study manual for the module on Professional Development. This learning outcome states that they need to be able to assess their own teaching practice and the teaching practices of their peers and other higher education practitioners. As professional self-regulated learning is integral to my practice I have designed a feedback questionnaire that focuses on both the contribution of the lecturer and the contribution of students to the effectiveness of learning opportunities. Reflecting on their contribution is aligned with the principles of professional self-regulated learning.

Next I report the qualitative feedback of the 2017 cohort of PGCHE students. The questionnaire was used as part of a learning opportunity that focused on student feedback. The questionnaire was administrated as a mid-year feedback opportunity. The outcome was discussed during the second semester - as an extension of the learning opportunity on student feedback. The same questionnaire was to be administered by the end of the academic year in November.

An auto-ethnographic lens makes one aware that receiving feedback from students is emotional and closely linked to intrapersonal intelligence. It is also something that happens in an education context, which represents social life education and teaching practice in my case. It is messy, uncertain and emotional. If we desire to research social life, then we must embrace a research method that, to the best of its (our) ability, acknowledges and accommodates mess and chaos, uncertainty and emotion (Adams \& Manning 2015). And auto-ethnography is a vulnerable, self-reflective form of writing.

In my many years of experience of 'putting myself as higher education practitioner out there' to be assessed by my students, I came to realise that the mid-year feedback more often than not is less positive than at the end of the academic year. In the middle of the year they still feel somewhat confused and find it difficult to cope with the demands of the programme and level of learning expected. These concerns are typical of students who have never been confronted by a transformational practice that expects them to take responsibility for their own learning and for constructing new meaning. By the end of the year the feedback is often quite different - more positive. In general it comes down to acknowledging: 'Oh, now I realise why you have offered the programme in this way'.

In Table 1 the qualitative feedback of the students is listed per respondent. Where applicable, it is indicated if more than one respondent were of the same or similar opinion. Only Section A - feedback on the lecturer's contribution - is reported. This section is divided into three open-ended 
TABLE 1: Qualitative feedback of Postgraduate Certificate in Higher Education students on my facilitating learning.

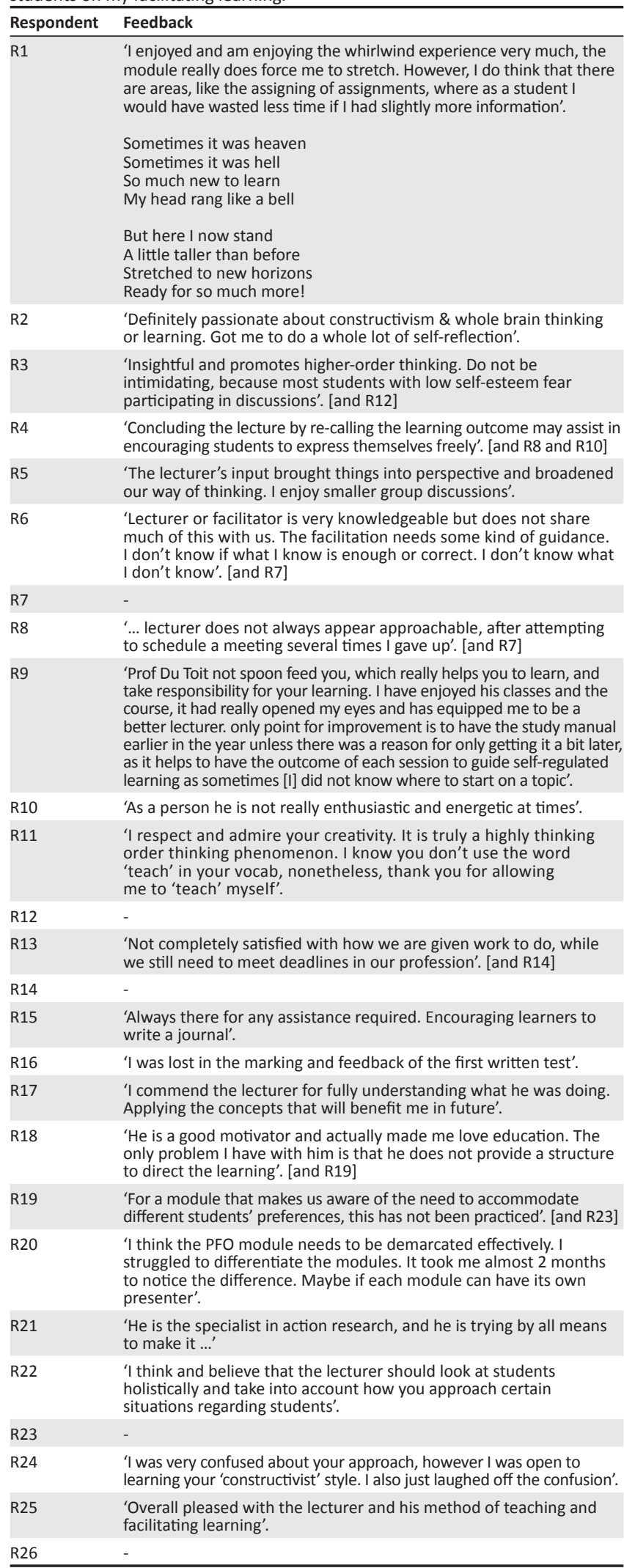

PFO, Professional Development.

subdivisions. The heading 'General comments' invited students to give feedback by means of short narratives. Each respondent is coded as R1, R2, R3 and so forth. One of the respondents (R1) wrote his or her feedback in the form of a poem consisting of two stanzas. Writing a poem on participatory action research was one of the tasks they had to execute during a learning opportunity on action research. The two stanzas appear as a separate 'narrative' below Table 1. The feedback that followed after the stanzas is tabled.

Consequently I offer examples of objects I use. They serve as symbols of what I consider as part of who I am as a higher education practitioner - answering the ontological question posed above. At the same time it is used to demonstrate how objects can be used for promoting creativity and getting students to actively participate. By means of the tasks to be executed, the constructing of new meaning is promoted.

\section{Objects}

Next I report by means of photo evidence how I use objects as part of my professional development trajectory. In using objects I act as role model to my students, and I expect them to do the same. The first encounter they have in using objects is when they have to bring an object that would best describe who they are as a higher education practitioner. This is the first task they receive to enact on the day of the commencement of the programme. It comes in the form of a wedding invitation: The marriage between the scholarship of teaching and research scholarship. This I do with a view to inculcating the importance of doing research and publishing on the outcome of the research - as universities expect them to do. I use action research to introduce them to the world of research and to narrow the gap between teaching and research. Executing an action research project of their own practice and reporting the outcome by means of a draft publication as alluded to above serves as an authentic assessment opportunity, as they do not sit for a written examination of 3 hours at the end of the year.

Each student receives the invitation in the form of a rolled-up invitation on marble paper tied with a silver ribbon to make the look and feel authentic. The narrative of the invitation can perhaps not be read, but it gives the reader an idea of where my practice starts (Figure 5).

The object I bring to the next session during which they have to introduce themselves is a baobab tree. It is made of hundreds of pieces of wire. It is an object of art that I bought from a creative and proud South African. He sells his art as part of his informal small business enterprise on the pavement.

I keep the original object in my office. It constantly reminds my students of why I have chosen it as a metaphor for my teaching practice. When I am visited by other people it usually becomes an object that initiates conversation and further discussion. Figure 6 shows what it looks like. 


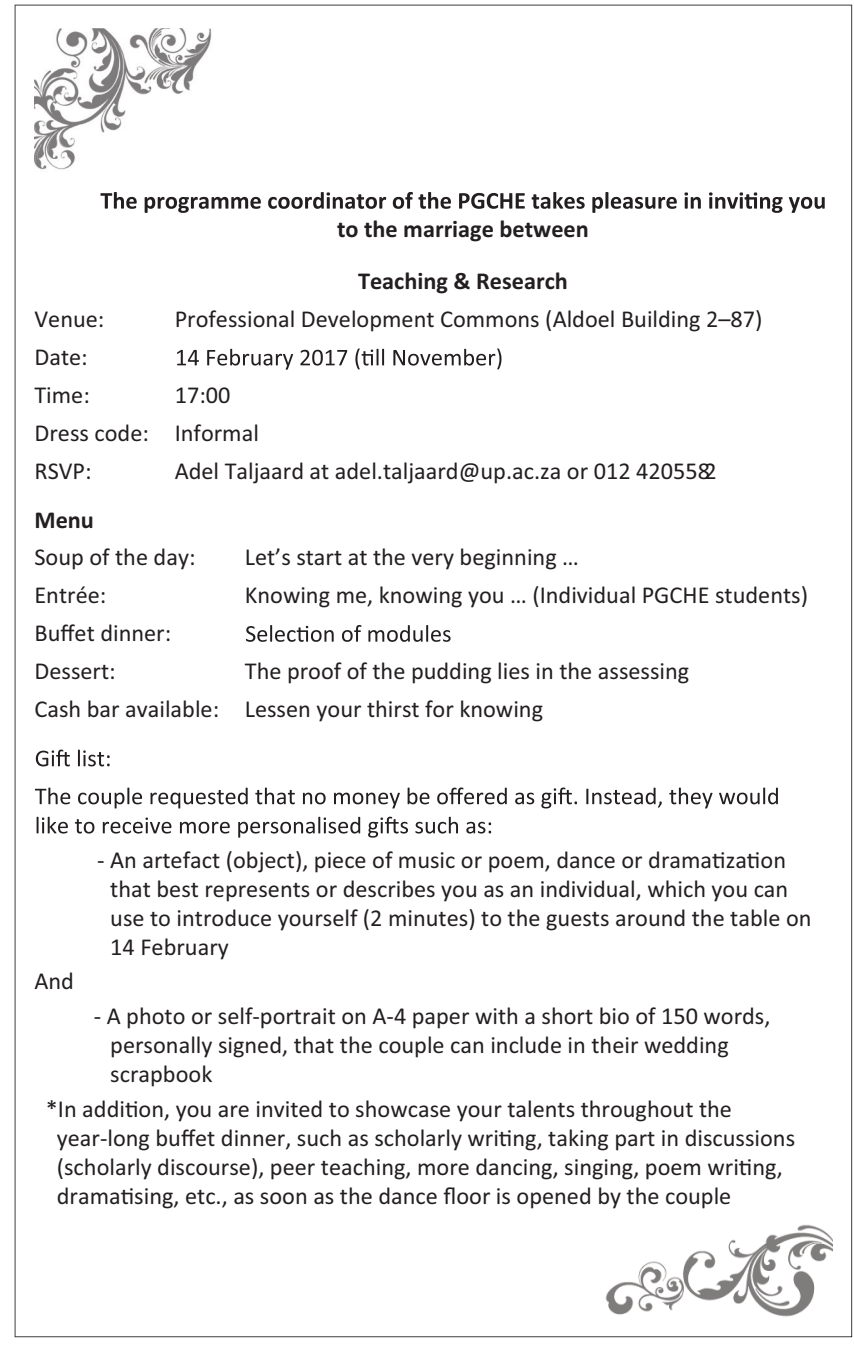

FIGURE 5: Example of invitation.

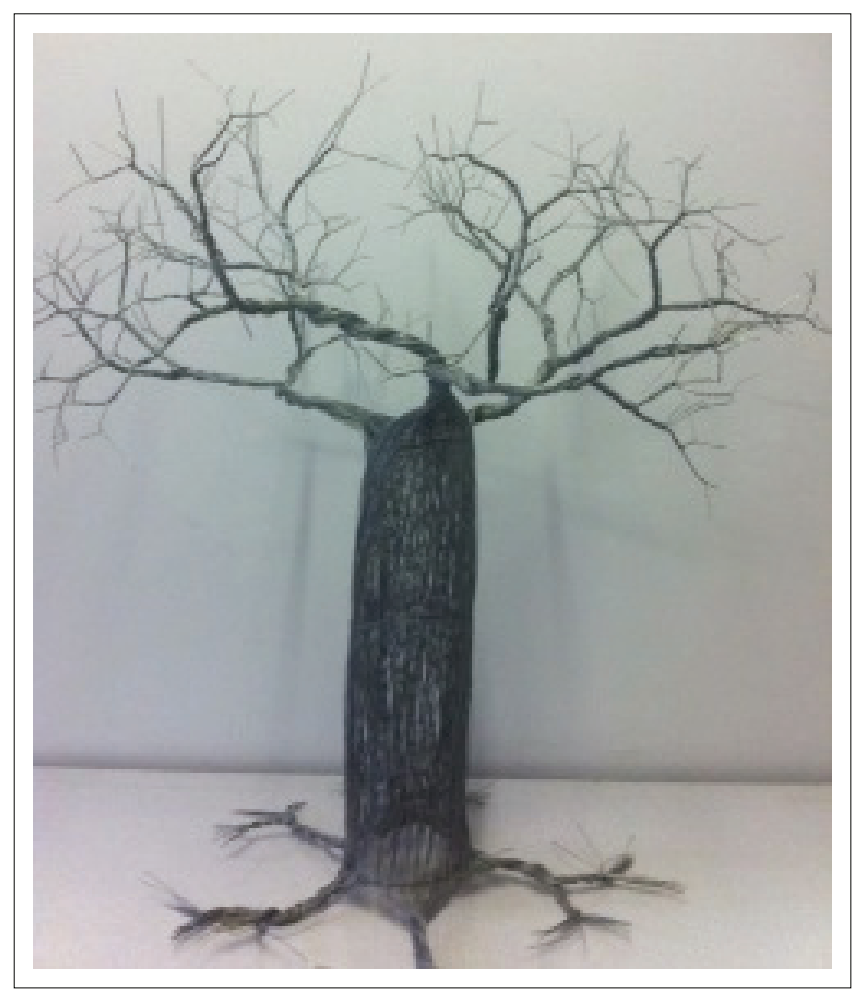

FIGURE 6: Baobab tree.
In essence the baobab is considered by the San people as a tree of wisdom - a tree that was turned upside down. This is exactly what I intend to do during each academic year - to turn my students upside down. I do this with a view to offering them the opportunity to think in a different, innovative way of looking at their teaching practice. I want them to become transformational in what they do to improve the quality of their teaching and their students' learning. The photo is included in their study manual.

When introducing students to the idea of action research of practice, I use balloons as objects. The collage in Figure 7 is evidence of how the balloons are used as objects and to what extent students actively participate. The balloons as objects create an atmosphere of fun - addressing the $\mathrm{D}$ quadrant of the whole brain model. In addition it allows for learning from one another - an attribute of the $C$ quadrant.

Playing cards, bears and hats (aligned with Herrmann's [1995, 1996] notion of whole brain thinking), and building paper towers (demonstrating the principles of cooperative learning and reflection) are all objects that form part of my object trajectory. Owing to space limits, I show how the different objects are combined. Figure 8 was part of an exhibition during an international conference funded by the National Research Foundation: International Research Symposium and Exhibition. 'Not just an object': Making meaning of and from everyday objects in educational research (Du Toit 2016b).

\section{Meta-reflection}

My use of the construct meta-reflection is based on the notion of metacognition - thinking about one's thinking. Here I am reflecting on my reflection. I use my auto-ethnographic lens to zoom in on my reflection and the way I use autoethnography to tint my action research.

I consider my reflection as multilayered. I reflect on self. I co-reflect with other scholars. I reflect on my teaching practice, my assessment practice, supervision practice and the way in which I conduct my research. My reflection is scholarly. And I reflect before I do (plan), while I do (enact) and after I have done what I have intended to do - by asking others and doing self-observation. Self-assessment becomes intrapersonal reflection. And I reflect on the poems I write.

So, true to my advocacies I would like to conclude with the same I expect of my students. I wrote a poem (Figure 9) as a response to the chapter I wrote (Du Toit 2014) in Vandeyar (2014). During a seminar we had to report on our experience of writing the chapter and being part of a scholarly community of practice who all contributed to the publication. 

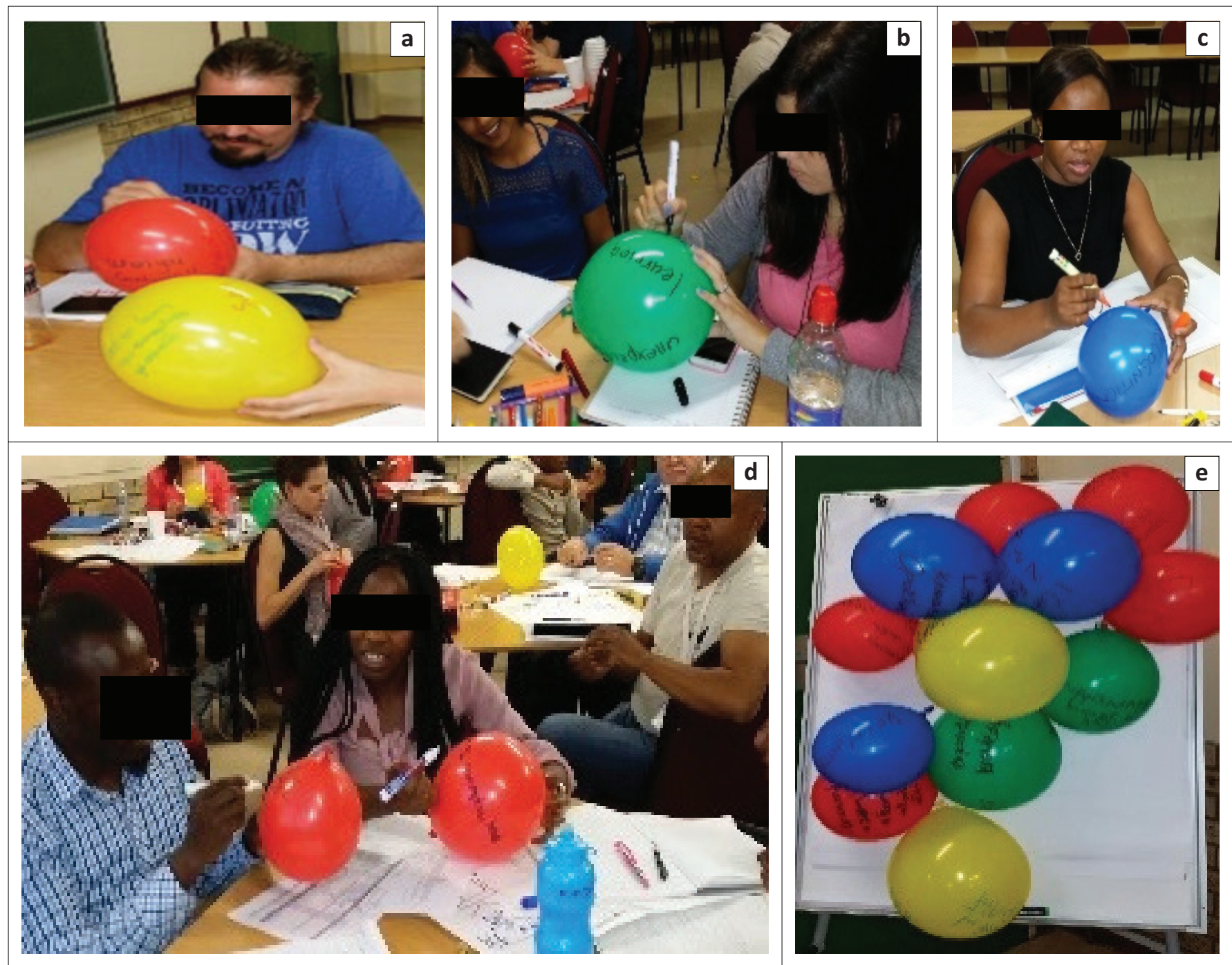

FIGURE 7: Balloons used as objects.
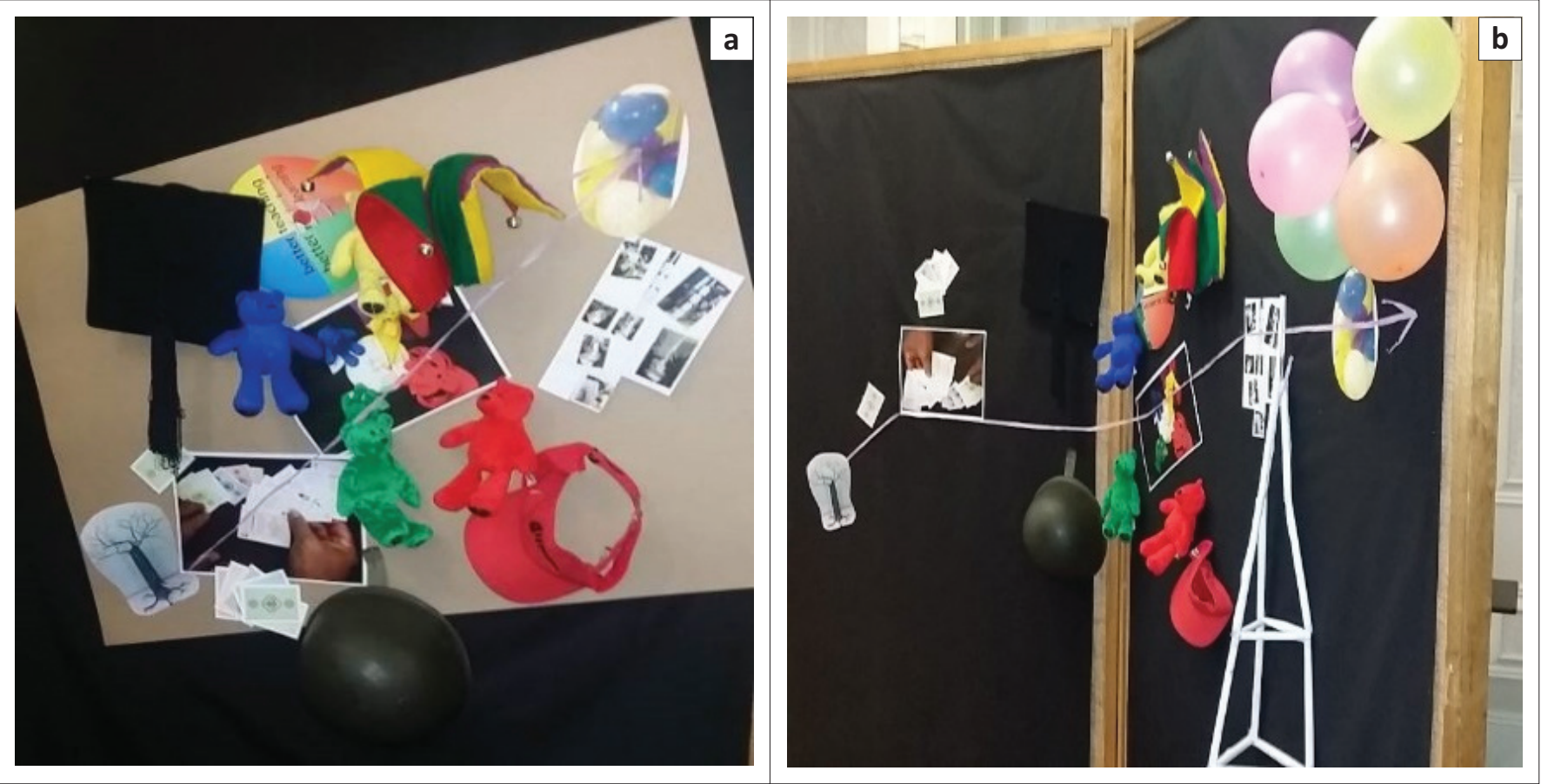

FIGURE 8: Exhibition. 


\author{
Meta-auto-ethnographic lens \\ Pieter du Toit \\ Contemplating my life \\ Scholarly life per se \\ Consisting of living acts: \\ Enacting principles of \\ Read \\ Write \\ Discourse \\ Scholarly self-discourse most often than not \\ Reflecting on my intrapersonal scholarly being
}

Back some 20 plus years

Along the road being questioned:

What do you profess, what do you profess, what do you profess?

Refrains my - seemingly - scholarless mind

Learn I had to learn

And unlearn

Construct to deconstruct to reconstruct to co-construct

Making meaning per socio-constructivist epistemology

Realisation sits:

Then - scholar

Still - scholar in the making

I embroidered year in, year out

Through the eyes of needles of all sorts

Colourful threads, thick and thin

My scholarly tapestry - my chapter metaphor

From exclusive white my experience; my practice

Non-real life settings

To inviting multicoloured

Real life

Authentic

Taking multicultural groups to lowa State University

Multicultural focused programme

Oklahoma next

Postdoctoral in Vlaanderen

I advocate, I advocate, I advocate

Action research and living theory

(McNiff, Whitehead and alike)

Using the full mental capacity of doing; multiple intelligence

Different ways of thinking - each one's preference

Differently intelligent

Theory only not, in combination with what I practice - yes

And forever the repeat:

Practice what you preach, what you preach, what you preach

Role model multidimensional practice

Cutting-edge curriculum development

Accountable assessment

Facilitating quality learning

Scholarship of teaching

Community engagement

(Read some roles of educators)

Practice in a multicultural setting

Which we did not learn

Experiential we did

Thanks to Kolb (1984)

Sometimes the gravel path unexpectedly shook and rattled; still does Laughed at

Such:

Your stuff on whole brain thinking will bring you nowhere

Utterance of (former) next-door colleague

Not?

But yet the scholarly output:

Whole brain learning in higher education

Subtitled: Evidence-based practice

Internationally acclaimed by Elsevier

More colour to my lens:

'Whole brain auto-ethnography'

Need to rest my case?
Back to what I advocate

Community of scholarly practice

Embroiderers

'Scholarly tapistrists' (meaning making) adding colour to practice

Scholarly reflection on practice

Says Fringe (2013)

From good practice, best, innovative, transformed

(Rooke \& Torbert 2005)

Account for the claims we make

Transformational leadership

Agents of change no more

'Agents of transformation' (meaning making became my game)

As my AR model, asset-based, proposes: highest quality!

Asset?

Us - you and I, human resources

Ontological a question

Who am I?

Who are we?

Developing our fullest potential

(Slabbert et al. 2009)

Self-driven, self-regulated professional learning

The university does see?

In some cases

Indeed

Education innovation awards

At last, recognition

Taking a leadership position

Higher education consulting:

Department of Family Medicine - more awards

... a stitch in my tapestry ...

Stitching further

Department of Information Science

... stitch ...

Moreover, Laureate: peer mentoring a young scholar from Taxation

... another stitch in my tapestry

... and another ... and another ... and another ...

And many more through my beloved PGCHE

Communities of practice

Reciprocal the professional learning

Scholarly output however without, all in vain

So, I convert and convert - align with 'research-intensive university'

Academic staff development, my field, I do not touch

Unless

Marriage between scholarship of teaching and research scholarship I claimed

And action research prevails:

Approach to self-empowerment

New meaning: 'auto-ethnographic self-empowerment'

A continuous spiral; multiple cycles; different steps

And stitch by stitch each, we, I create

Tapestries of living theory

Practice tapestry

Through insider research

Self-study (Pithouse et al.)

Research-driven practice (Du Toit 2012

Practitioner-researchers we are

My eyes encountered sentence after sentence; still do

English, English, some Germaans

German words highlight the mind:

Historische Sozialforschung

(Ellis, Adams \& Bochner 2011)

Hochschule im Wandel: Die Universität als Forschungsgegenstand

(Ulrich Teichler)

Flemisch alike

Leren, Onderwijzen en Leren Onderwijzen

(Vincent Donche 2005)

'Tapestry' my construct of choice

Embroidering mine, pure satisfaction

And yours?

And as scholarly community of practice?

A scholarly multicultural tapestry - our masterpiece

Intra- and interpersonal ontological the design 
As I entered my article with an intermezzo, I take liberty in exiting with a fanfare.

\section{Acknowledgements Competing interests}

The author declares that he has no financial or personal relationships that may have inappropriately influenced him in writing this article.

\section{References}

Adams, T.E. \& Manning, J., 2015, 'Autoethnography and family research', Journal of Family Theory and Review 7(4), 350-366. https://doi.org/10.1111/jftr.12116

De Boer, A., Du Toit, P.H. \& Bothma, T., 2015, 'Activating whole brain ${ }^{\circledast}$ innovation: A means of nourishing multiple intelligence in higher education', The Journal for Transdisciplinary Research in Southern Africa 11(2), 55-72. https://doi.org/10.4102/ td.v11i2.78

De Boer, A., Du Toit, P.H., Scheepers, D. \& Bothma, T., 2013, Whole Brain ${ }^{\circledR}$ Learning in higher education: Evidence-based practice, Chandos, Oxford.

Department of Education, 2000a, Curriculum 2005, Lifelong learning for the 21st Century. A user's guide, Government Printer, Pretoria.

Department of Education, 2000b, Norms and standards for educators, Government Printer, Pretoria.

Donche, V. 2005, Leren, onderwijzen en leren onderwijzen. Academia Press, Gent.

Du Toit, P.H., 2014, 'An auto-ethnographic lens on lecturer professional development', in S. Vandeyar (ed.), Good practice in culture-rich classrooms: Research-informed perspectives, pp. 254-281, Oxford University Press, Cape Town.

Du Toit, P.H., 2016a, 'An ethnographic account of a snapshot in Professor Graham Duncan's journey of educational professionalism', HTS Teologiese Studies/ Theological Studies 72(1), a3275. https://doi.org/101402.v72i1.3275

Du Toit, P.H., 2016b, 'A pair of scissors, 15 A-4 pages and cello tape: A constructivist equation to making meaning of self-regulated and cooperative learning', in International Research Symposium and Exhibition, 'Not Just an Object': Making Meaning of and from Everyday Objects in Educational Research, February 03-05, Maharani Hotel, Durban.

Du Toit, P.H., 2017, 'Linking multiple intelligence and thinking preferences as a mean to facilitating multiliteracies: Evidence-based practice', in A. Engelbrecht (ed.) Manuscript of a publication on multiliteracies, in press, Van Schaik, Pretoria.

Du Toit, P.H. \& Van Zyl, A., 2006, 'Birthing an action research scholar', ALAR Journal $11(1), 82-100$.

Ellis, E., Adams, T.E. \& Bochner, A.P., 2011, ' Autoethnography: An overview.' Historical Social Research/Historsiche Sozialforschung, 36(4), 273-290.
Fringe, J.J. dos, S.F., 2013, 'Promoting critical reflection for academic professional development in higher education', PhD thesis, University of Pretoria.

Gardner, H., 1993, Multiple intelligences: The theory into practice, Basic Books, New York.

Giloi, S. \& Du Toit, P.H., 2013, 'Current approaches to the assessment of graphic design in a higher education context', International Journal of Arts and Design Education 32(2), 256-268. https://doi.org/10.1111/j.1476-8070.2013.01758.x

Herrmann, N., 1995, The creative brain, Brain Books, Lake Lure, NC.

Herrmann, N., 1996, The whole brain business book, McGraw-Hill, New York.

Herrmann, N. \& Herrmann-Nehdi, A., 2015, The whole brain business book, 2nd edn., McGraw-Hill, New York.

Knowles, M., 1990, The adult learner: A neglected species, 4th edn., Gulf Publishing Company, Houston, TX.

Lucas, K., Dippenaar, S.M. \& Du Toit, P.H., 2014, 'Analysis of assessment practice and subsequent performance of third year level students in natural sciences', Africa Education Review 11(4), 563-583. https://doi.org/10.1080/18146627.2014.935004

Malan, S.P.T. \& Du Toit, P.H. (red.), 1991, Suksesvolle onderrig. Riglyne vir dosente, onderwysers en opleiers, Academica, Pretoria. [Successful teaching: Guidelines for lecturers, teachers and trainers.]

McNiff, J. \& Whitehead, J., 2006, All you need to know about action research, Sage, London, UK.

Rooke, D. \& Torbert, W.R, 2005, 'Seven transformations of leadership', Harvard Business Review, April, viewed 22 September 2011 from http://hbr.org/2005/04/ seven-transformations-ofleadership/ar/1

Slabbert, J.A., De Kock, D.M. \& Hattingh, A, 2009, The brave 'new' world of education: Creating a unique professionalism, JUTA, Cape Town, South Africa.

Smit, T. \& Du Toit, P.H., 2016, 'Transforming beginner teacher mentoring interventions for social reform', South African Journal of Education 36(3), Art.\#1134, 12 pages, viewed from http://reference.sabinet.co.za/sa_epublication/educat

Van der Wath, A.E. \& Du Toit, P.H., 2015, 'Learning end-of-life care within a constructivist model: Undergraduate nursing students' experiences', Curationis 38(2), 1-9. https://doi.org/10.4102/curationis.v38i2.1537

Vandeyar, S. (ed.), 2014, Good practice in culture-rich classrooms: Research-informed perspectives, Oxford University Press, Cape Town.

Wium, A.M., Pitout, H., Human, A. \& Du Toit, P.H., 2017, 'An analysis of thinking preferences across three health care disciplines', Innovations in Education and Teaching International 54(1), 33-41. https://doi.org/10.1080/14703297.2015.11 17010

Wolvaardt, J.E., Cameron, D.C. \& Du Toit, P.H., 2013, 'The bottom line: Tailoring public health election to students' needs', African Journal of Health Professions Education 5(1), 14-18. https://doi.org/10.7196/ajhpe.196

Wolvaardt, G. \& Du Toit, P.H., 2012, 'Action research-driven professional development: Developing transformational health care managers and creating learning organisations', South African Journal of Higher Education 26(6), 1235-1249.

Wolvaardt, L., Lindeque, B.G. \& Du Toit P.H., 2016, 'Balancing the educational choices in the decision making of a dean of medicine: Fission or fusion?', African Journal of Health Professionals Education 8(1), 25-29. https://doi.org/10.7196/AJHPE.2016.v8i1.474 